\title{
Nutrisi pada pengguna gigitiruan penuh Nutrition for the wearer of full denture
}

\author{
${ }^{1}$ Nur Huda Alimin, ${ }^{1}$ Hermiati Daharudin, ${ }^{2}$ Harlina \\ ${ }^{1}$ Dokter gigi \\ ${ }^{2}$ Bagian Ilmu Penyakit Mulut, Fakultas Kedokteran Gigi, Universitas Hasanuddin \\ Makassar, Indonesia
}

\begin{abstract}
People's health mainly depends on the intake of nutrients intake. It is well known that tooth loss affects health, although it could be restored by prosthodontic treatment. Denture wearer's diet usually consists of soft foods. This kind of diet will limit the variety of foods consumed by the elderly, and increasing the risk of nutrition deficiencies. Inadequate nutrition for a long time could lead to various kinds of diseases, even the systemic, which primarily occurs in the mouth because of clinical symptoms of early malnutrition firstly found in the mouth. The risk of nutritional emergencies could increase along with the aging. The understanding of nutritional supply, consumption problem of elderly, and symptoms of nutrition disorder could help dentists identifying denture patiens with nutrition disorder risk and could give solutions for them.
\end{abstract}

Key words: elderly, denture, nutritional disorder, nutrient

\begin{abstract}
ABSTRAK
Kesehatan tubuh seseorang utamanya bergantung pada asupan nutrien yang dikonsumsi. Sangat disadari bahwa kehilangan gigi akan mempengaruhi kesehatan, walaupun dapat dikembalikan dengan perawatan prostodontik. Diet pemakai gigitiruan biasanya terdiri atas makanan lunak. Diet semacam ini akan membatasi variasi makanan yang dikonsumsi serta meningkatkan resiko tidak tercapainya jumlah nutrien tertentu yang diperlukan oleh tubuh. Nutrisi yang tidak mencukupi dan berlangsung lama dapat memicu terjadinya berbagai jenis penyakit hingga penyakit sistemik, yang utamanya terjadi dalam mulut karena gejala klinis malnutrisi mula-mula ditemukan di dalam mulut. Risiko kegawatan nutrisi meningkat seiring dengan penuaan. Pemahaman tentang kebutuhan nutrisi, masalah konsumsi pada manula, serta gejala gangguan nutrisi dapat membantu dokter gigi untuk mengidentifikasi pasien pengguna gigitiruan yang memiliki risiko gangguan nutrisi, sekaligus dapat memberikan solusi kepada pasien tersebut.
\end{abstract}

Kata kunci: manula, gigitiruan, gangguan nutrisi, nutrien

Koresponden: Nur Huda Alimin, Jl. Bonto Mene 2 No.09 Makassar 90222.E-mail: gigiuh06_udha@yahoo.com

\section{PENDAHULUAN}

Gigi geligi memiliki fungsi yang sangat penting bagi kehidupan seseorang. Selain untuk estetik dan komunikasi, gigi geligi juga memiliki peran yang besar dalam pemenuhan nutrisi seseorang dengan fungsi mastikasinya.

Pengunyahan makanan penting untuk proses pencernaan makanan,terutama untuk sebagian besar buah dan sayuran mentah,karena memiliki membran selulosa yang tidak dapat dicerna di antara bagianbagian zat nutrisi yang harus diuraikan sebelum makanan dapat digunakan. Mengunyah makanan akan membantu pencernaan makanan untuk alasan sederhana karena enzim-enzim pencernaan hanya bekerja pada permukaan partikel makanan, dan kecepatan pencernaan sangat bergantung pada area permukaan total yang terpapar dengan sekresi usus. Selain itu, menggiling makanan hingga menjadi partikel-partikel dengan konsistensi sangat halus akan mencegah ekskoriasi traktus gastrointestinal dan memudahkan pengosongan makanan dari lambung ke dalam usus halus, dan kemudian ke semua segmen usus berikutnya.,
Status kesehatan gigidapat mempengaruhi status nutrisi seseorang. Kehilangan banyak gigi akan mempengaruhi kemampuan mastikasi yang diyakini memiliki dampak negatif terhadap kesehatan umum dengan menyebabkan terjadinya pembatasan diet tertentu dan asupan nutrien yang sangat dibutuhkan tubuh. Kehilangan gigi telah dihubungkan dengan perubahan dalam pemilihan makanan dan gangguan nutrisi pada manula. ${ }^{3,4}$

Gigitiruan tidak dapat mengembalikan fungsi yang sama baiknya bila dibandingkan dengan gigi geligi alami,bahkan pengguna gigitiruan melaporkan mengalami kesulitan dalam mengkonsumsi berbagai jenis makanan,termasuk buah-buahan segar, seperti apel dan pir,dan sayur-sayuran mentah.Laporan dari World Health Organization pada tahun 2003 menyimpulkan bahwa terdapat bukti yang kuat diet buah-buahan dan sayuran yang tinggi $(>400 \mathrm{~g} / \mathrm{d})$ dapat mencegah obesitas, diabetes, penyakit kardiovaskular, dan beberapa kanker.,

Hampir separuh manula menghadapi gangguan nutrisi yang dapat diidentifikasi secara klinis.Risiko kegawatan nutrisi lebih besar dengan meningkatnya 
usia; manula yang berusia lebih dari 70 tahun cenderung memiliki diet yang lebih buruk. Karena mayoritas orang tak bergigi berusia lanjut, diduga banyak pengguna gigitiruan mempunyai masalah nutrisi. Selain kondisi gigi geligi dan pola diet, keadaan gizi pemakai gigitiruan dipengaruhi oleh faktor sosioekonomi,penyakit degeneratif,konsumsi obat yang disertai pantang makanan tertentu, serta penggunaan makanan penambah gizi. Shinkai dkk, juga menambahkan bahwa tingkat pendidikan, informasi dan pengetahuan tentang kesehatan dan nutrisi, rasa dan kecenderungan seseorang, jenis kelamin, dan suku, juga mempengaruhi pilihan diet dan nutrisi seseorang. ${ }^{3,4}$ Oleh karena itu,pemahaman tentang kebutuhan nutrisi, masalah konsumsi pada orang tua, serta gejala gangguan nutrisi membantu dokter gigi mengidentifikasi pasien gigitiruan yang memiliki risiko gangguan nutrisi. ${ }^{4}$

Pada makalah ini akan diberikan informasi tambahan bagi dokter gigi yang khususnya merawat pasien berusia lanjut pengguna gigitiruan, agar dengan adanya gigitiruan baru status nutrisi manula dapat meningkat.

\section{TINJAUAN PUSTAKA}

Gejala klinis malnutrisi mula-mula ditemukan di dalam mulut. Karena cepatnya pertukaran sel di dalam mulut, asupan nutrien secara teratur dan berimbang sangat diperlukan untuk mempertahankan epitel mulut. Penelitian yang dilakukan oleh Boreti yang dikutip oleh Bradbury dkk, bahwa pengguna gigitiruan memiliki kemampuan mengunyah yang lebih rendah dibandingkan dengan individu yang bergigi, yang diukur baik secara objektif maupun subjektif. $^{5}$ Orang yang tidak bergigi dilaporkan bahwa pilihan makanan mereka terpengaruh karena menggunakan gigitiruan. Diet pengguna gigitiruan yang biasanya terdiri atas makanan lunak yang membatasi variasi makanan yang dikonsumsi serta meningkatkan resiko tidak terpenuhinya nutrien tertentu. Hal ini dapat memicu terjadinya penyakit mulut hingga penyakit sistemik. ${ }^{5,6}$

Keadaan gizi yangmemadai akan meningkatkan toleransi mukosa mulut terhadap gigitiruan yang baru dan memperkecil kemungkinan penolakan. Karena pembuatan gigitiruan butuh serangkaian kunjungan, analisis dan penyuluhan diet yang sebaiknya dimasukkan sebagai bagian dari perawatan. ${ }^{3,6,7}$

\section{Keadaan dan kebutuhan nutrisi manula}

Kebutuhan gizi manula ditentukan oleh kecepatan terjadinya penuaan, kesehatan umum, dan tingkataktivitas fisik.Jadi sulituntukmenyatakan bahwa persyaratan energi,vitamin,dan mineral yang memadai dan berlaku umum bagi semua manula, karena penurunan metabolisme basal dan aktivitas fisiknya, energi yang dibutuhkan oleh manula juga menurun dengan bertambahnya usia.Seiring dengan penuaan, massa tubuh yang tidak berlemak diganti dengan lemak. Hal ini menyebabkan penurunan kecepatan metabolisme. Permulaan penyakit kronik biasanya menyebabkan penurunan aktivitas fisik. ${ }^{6}$

Persentase kehilangan gigi pada manula cukup besar mengingat populasinya dari tahun ke tahun semakin tinggi. Pernyataan Joshipura dkk, seperti yang dikutip dari penelitian yang dilakukan oleh Sheiham dkk, adalah ditemukan orang-orang yang tak bergigi mengkonsumsi lebih sedikit sayuran, serat, dan karoten dibandingkan dengan mereka yang memiliki lebih dari 25 gigi. Kehilangan gigi dihubungkan dengan asupan yang lebih sedikit pada makanan yang keras untuk dikunyah seperti apel dan wortel. Adapun penelitian lain yang dikutip oleh Sheiham dkk,yang menganalisis efek statuskesehatan gigi terhadap konsumsi non-strach polysaccharida, dilaporkan penurunan asupan dengan hilangnya gigi. ${ }^{2,7,8}$

Pengaruh berbagai kondisi rongga mulut pada status nutrisi memiliki hubungan yang penting terhadap asupan nutrien. Beberapa penelitian telah mengembangkan hubungan antara asupan nutrien, status nutrisi,dan berbagai macam penyakit sistemik. Defisiensi vitamin pada manula cenderung subklinis, tetapi tiap ketegangan tubuh dapat menyebabkan berkembangnya gejala-gejala klinis pada orang tersebut. Asupan vitamin D dan $\mathrm{B}_{6}$, dan asam foliat yang rendah paling sering dilaporkan. Sebuah penelitian yang dikutip oleh Christine dkk, menunjukkan dengan jelas hubungan langsung antara asupan buah dan sayuran, dan perkembangan penyakit kardiovaskular. Selain itu, peningkatan asupan buah dan sayuran juga telah dihubungkan dengan risiko stroke yang lebih rendah. ${ }^{8}$

Goerge dkk, dalam bukunya menulis bahwa sebuah surva menunjukkan asupan protein menurun dengan bertambahnya umur,tetapi defisiensi protein tampaknya jarang terjadi pada orang tua yang sehat di negara-negara barat.Lemak merupakan 37\% dari seluruh kalori di dalam diet rata-rata orang dewasa. Karena meningkatnya bukti epidemiologi termasuk yang dikutip oleh Christine dkk, dari beberapa hasil penelitian sebelumnya, menyatakan bahwa asupan lemak jenuh dari berbagai makanan, berimplikasi penyakit kardiovaskuler dan memainkan peranan penting dalam meningkatkan risiko penyakit kanker tertentu. Untuk hal tersebut, maka orang dewasa disarankan mengurangi asupan lemaknya sampai $30 \%$ dari jumlah kalori. ${ }^{6,8}$ 
Defisiensi vitamin D dapat terjadi pada manula yang terus-menerus tinggal di rumah dan jarang terkena sinar matahari. Karena pentingnya vitamin D dalam metabolisme kalsium, maka asupan yang cukup sangat penting. Gejala malnutrisi oral biasanya akibat dari kurangnya vitamin B kompleks. Lidah panas atau nyeri mulut akibat gigitiruan disebabkan oleh gangguan nutrisi, utamanya kekurangan vitamin tersebut dan zat besi. ${ }^{6}$

Diet anti-oksidan atau serat telah terbukti dapat mengurangi risiko penyakit kardiovaskuler. Buahbuahan dan sayuran, serta vitamin, dan mineral individu, mengurangi efek penyakit yang terjadi melalui beberapa mekanisme, termasuk melindungi dengan cara melawan pengaruh buruk radikal bebas, modulasi produksi sitokin, meningkatkan fungsi endotelial, serta mengubah parameter koagulasinya. Meskipun asupan vitamin $\mathrm{C}$ pada manula biasanya tinggi,dilaporkan bahwa kadar asam askorbat dalam darah rendah. Oleh sebab itu, pemakai gigitiruan dianjurkan mengkonsumsi makanan yang banyak mengandung vitamin $\mathrm{C}$ setiap hari, seperti jeruk, melon, tomat, brokoli atau cabai). ${ }^{6,8}$

Dua jenis mineral, kalsium dan seng, sangat diperlukan bagi manula.Defisiensi seng yang ringan diduga terjadi pada beberapa manula di Amerika. Penyembuhan jaringan dan fungsi imun dipengaruhi oleh status seng.Sumber zat seng yang biologis ialah produk hewani. Kebutuhan zat besi pada wanita munurun pada saat menopaus. ${ }^{6}$

\section{Dampak penggunaan gigitiruan pada status nutrisi manula}

Beberapa riset menunjukkan bahwa asupan diet individu, utamanya yang tidak bergigi, cenderung tidak terpenuhi karena mengkonsumsi terlalu sedikit asupan yang kaya nutrien dan terlalu banyak asupan yang kaya akan kalori dan tinggi lemak, dibandingkan dengan subjek yang bergigi. Riset yang dilakukan pada manula di Swedia, menemukan bahwa pria yang tidak bergigi mengkonsumsi lebih sedikit buah dan sayuran dibandingkan dengan pria bergigi. ${ }^{2,3,6,8}$

Riset oleh Sheiham dkk, menemukan bahwa asupan serat pada orang bergigi lebih tinggi dan secara signifikan dihubungkan dengan jumlah gigi dan oklusi. Serat merupakan komponen diet yang penting, khususnya dihubungkan dengan kesehatan gastrointestinal. Pengguna gigitiruan penuh terlihat mengkonsumsi diet yang kualitas yang sama seperti orang yang bergigi tapi mungkin dalam bentuk yang lebih disesuaikan. Sebagai contoh, beberapa cara yang digunakan oleh pemakai gigitiruan untuk makan termasuk mengubah bentuk dari makanan agar lebih mudah dikunyah dengan memasaknya lebih lama atau dengan menghaluskannya. Akan tetapi, cara tersebut dapat menyebabkan banyaknya kandungan vitamin yang hilang, karena vitamin mengalami denaturasi saat dimasak., ${ }^{2,4}$

Asupan nutrien pemakai gigitiruan lebih rendah dari mereka yang memiliki gigi alami.Pria pemakai gigitiruan menunjukkan asupan yang lebih rendah dibanding wanita pemakai gigitiruan. Khususnya asupan kalori rata-rata, protein, vitamin $\mathrm{A}$, asam askorbat,piridoksin,danasam folat pada pria pemakai gigitiruan lebih rendah dari pria bergigi alami. Asupan kalsium serta protein pada wanita pemakai gigitiruan lebih rendah dari wanita yang bergigi alami. Adapun penelitian yang menyebutkan bahwa pengguna gigitiruan mengkonsumsi vitamin A dan $\mathrm{C}$, dan kalsium yang lebih rendah dibanding dengan yang bergigi.Penelitian yang dilakukan pada manula di Swedia, menyebutkan bahwa kurang sesuainya gigitiruan rahang berhubungan dengan menurunnya asupan vitamin C. $^{6,8}$

Ketidakmampuan membedakan kualitas sensorik makanan dapat menurunkan asupan kalori.Penurunan rasa dan ketajaman penciuman adalah bagian dari proses penuaan; karena itu sulit untuk memisahkan pengaruh proses penuaan dan pengaruh pemakaian gigitiruan pada ketajaman sensor. Hampir semua pasien melaporkan penurunan ketajaman rasa saat gigitiruan pertama kali dipasang.Hal ini disebabkan oleh penutupandaerah palatum keras.Bagaimanapun juga, hal ini biasanya bersifat sementara dan pada hampir semua orang kemampuan untuk merasakan akan kembali beberapa bulan setelah pemasangan gigitiruan. ${ }^{6}$

\section{Komunikasi dan konseling nutrisi}

Komunikasi merupakan hal yang sangat penting karena menjadi wadah berbagi informasi. Komunikasi melibatkan pemahaman yang lebih dalam terhadap pasien. Komunikasi termasuk kemampuan untuk mendengar, empati, dan membangun kepercayaan hubungan antara dokter-pasien.Dokter gigi dianggap memiliki kemampuan teknik yang hebat, mampu memberi solusi yang cepat dan terbaik, dan berkomunikasidengan sabar dan efektif pada pasien. Ahli prostodonsi harus mengetahui sepenuhnya kondisi pasiennya. ${ }^{9}$

Kehilangan gigi dan menggunakan gigitiruan dapat membuat individu mengalami tekanan. Untuk pasienyangkurangberuntung dan kehilangan semua giginya, kenyamanan, dan gigitiruan penuh yang efisien tidak bisa terlalu diharapkan. Setidaknya ada tiga tujuan komunikasi antara dokter-pasien, yaitu membangun hubungan interpersonal yang baik, bertukar informasi, danmembuat pilihan perawatan. ${ }^{9}$ 
Salah satu harapan pasien yang menginginkan gigitiruan baru adalah agar mereka dapat makan makanan yang lebih bervariasi. Jadi, pasien-pasien tersebut seringkali bersedia menerima saran-saran yang ditujukan untuk memperbaiki kualitas diet. Pemeliharaan nutrisi harus dimulai pada perjanjian pertama agar konseling dan kelanjutannya dapat terlaksana selama masa perawatan.Dengan petunjuk dan dorongan yang terus-menerus dari tim dokter gigi, pasien akan lebih mudah untuk melakukan perubahan tetap pada pola makannya. ${ }^{6}$

Tujuan utama dari konseling diet untuk pasien prostetik adalah memperbaiki ketidakseimbangan asupannutrisi yang dapat mengganggu pemeliharaan jaringan mulut. Mengenali kebutuhan nutrisi pasien berdasarkan pemeriksaan visual atau wawancara sering sulit dilakukan. Evaluasi diet dan konseling dimasukkan jika pasien memang mempunyai faktor risiko; usia di atas 75 tahun, pendapatan rendah, hidup menyendiri, lesi-lesi mulut (glositits, keilosis, denture soremouth), resorpsi tulang yang signifikan, setiap hari minum lebih dari tiga jenis obat,penyakit persendian yang membatasi gerakan, penggunaan suplemen diet dosis tinggi,mengkonsumsi diet yang tidak seimbang, dan berpantang. ${ }^{3,6}$

Dokter gigi tidak diharapkan mendiagnosis defisiensi nutrisi, tetapi lebih untuk menentukan ketepatan diet secara umum. Jika pasien mengalami penurunan berat badan yang berlebih,atau hipertensi maupun diabetes yang tidak terkontrol, atau datang dengan perubahan jaringan mulut yang menandakan malnutrisi,harus dilakukan perujukan kepada dokter umum. ${ }^{6}$

\section{PEMBAHASAN}

Nutrisi pada pasien yang berusia lanjut hal sangat penting untuk diperhatikan, utamanya pada pasien pengguna gigitiruan karena kesehatan gizi mempengaruhi jaringan mulut serta kemampuan pasien menggunakan gigitiruan. Karena cepatnya pertukaran sel di dalam mulut,asupan nutrien penting secara teratur dan seimbang sangat diperlukan untuk mempertahankan epitel mulut, ${ }^{6}$ pada pasien berusia lanjut yang fungsi tubuhnya telah melemah seiring dengan penuaan yang terjadi.

Fungsi pengunyahan sangat penting dalam penghalusan makanan, utamanya yang kaya akan berbagai nutrien penting yang sulit jika langsung dikonsumsi dan diserap tubuh tanpa dihaluskan terlebih dahulu. Selain itu, proses mastikasi juga diperlukan untuk mencegah ekskoriasi traktus gastrointestinal dan untuk memudahan pengosongan makanan dari lambung ke dalam usus halus dan kemudian ke semua segmen usus berikutnya. ${ }^{1}$
Kehilangan gigi pada pasien berusia lanjut dapat mempengaruhi asupan nutrien yang diperlukan oleh tubuh yang pada akhirnya dapat memicu terjadinya berbagai macam penyakit hingga penyakit sistemik yang diakibakan oleh defisiensi nutrisi, ${ }^{2-6,8}$ seperti beberapa hasil penelitian yang dilaporkan, yang menyebutkan ada hubungan yang signifikan antara kehilangan gigi dan asupan nutrisi khususnya pada manula.

Pemakaian gigitiruan tidak menjamin perbaikan fungsi mastikasi karena sering gigitiruan rahang bawah terlalu menekan jaringan di bawahnya, gigitiruan yang tidak stabil, dan iritasi gigitiruan yang menyebabkan rasa nyeri. ${ }^{8,10}$

Jika dibandingkan dengan orang dewasa bergigi lengkap atau pemakai gigitiruan sebagian, pemakai gigitiruan penuh akan memiliki kemampuan yang lebih rendah dalam indera perasa dan tekstur serta pengunyahannya juga lebih lambat. ${ }^{6}$ Gigitiruan diharapkan dapat memperbaiki atau mendukung fungsi mastikasi yang sudah berkurang pada pasien berusia lanjut dan meningkatkan status gizinya. Akan tetapi,terkadang dengan adanya gigitiruan baru belum dapat memperbaiki status gizi usia lanjut akibat berbagai kondisi yang telah disebutkan sebelumnya,sehingga seseorang harus cermat untuk membuat makanan tersebut dapat dikonsumsi oleh manula. Hal ini tentunya harus dilakukan dengan bantuan berbagai pihak, utamanya keluarga pasien untuk membantu manula melewati kehidupannya.

Perawatan gigitiruan pada manula tidak hanya sebatas memberikan gigitiruan baru, tapi juga harus memperhatikan keadaan umumnya agar perawatan yang dilakukan dapat memberikan kepuasan kepada dokter dan pasien. Pemahaman tentang kebutuhan nutrisi, masalah konsumsi pada manula, serta gejala gangguan nutrisi dapat membantu dokter gigi mengidentifikasi pasien gigitiruan yang memiliki risiko gangguan nutrisi. Jika ditemukan tanda-tanda klinis tersebut, dokter gigi sebaiknya mengambil langkahpendahuluan dengan memberikan konseling gizi pada pasien dengan tujuan memperbaiki status gizinya. Jika pasien mengalami masalah kesehatan umum atau gangguan nutrisi yang kompleks, sebaiknya dirujuk ke dokter ahli di bidang tersebut.

Selain itu, jika komunikasi antara dokter dengan pasien baik, memungkinkan dokter memperoleh informasi dan keluhan-keluhan yang dibutuhkan untuk merawat pasien, dan memudahkan dokter memberi instruksi dengan lebih baik pada pasien karena pasien perlu untuk mengerti dan dimengerti, utamanya pasien berusia lanjut. ${ }^{10}$

Dari pembahasan di atas, disimpulkan bahwa perawatan gigitiruan pada pasien usia lanjut harus 
dilakukan secara komprehensif. Selain kondisi gigi geligi dan pola diet,keadaan gizi pengguna gigitiruan dipengaruhi berbagai faktor,termasuk sosioekonomi, adanya penyakit degeneratif,kurangnya pengetahuan mengenai kesehatan dan nutrisi, ras, jenis kelamin, pemakaian obat yang disertai pantangan untuk mengkonsumsi makanan tertentu, serta penggunaan suplemen gizi. Selain melakukan perawatan pada pasien, juga diperlukan membangun komunikasi yang baik antara dokter-pasien, serta konseling gizi jika diperlukan pada pasien berusia lanjut. Jaringan mulut yang sehat dapat mendukung gigitiruan dengan baik dalam menahan tekanan gigitiruan, sehingga memberikan kenyamanan bagi penggunanya. Oleh karena itu, perawatan yang tepat harus didukung oleh kemampuan, pengetahuan, dan pemahaman dokter gigi mengenai kondisi yang umum terjadi pada manula.Jika dokter gigi menghadapi pengguna gigitiruan dengan gangguan nutrisi yang parah, sebaiknya segera merujuk pasien kepada ahlinya.

\section{DAFTAR PUSTAKA}

1. Guyton AC, Hall JE. Buku ajar fisiologi kedokteran. Ed.9. Alih bahasa: Setiawan I. Jakarta: EGC; p.999-1000.

2. Sheiham A, Steele JG, Marcenes W, Lowe C, Finch S, Bates CJ, et al. The relationship among dental status, nutrient intake, and nutritional status in older people. J Dent Res [serial on the Internet] 2001 [cited 2010 Aug 14]; 80 (2): 408-13. Available from: URL:http://jdr.sagepub.com/content/80/2/408.

3. Bradbury J, Thomason JM, Jepson NJA, Walls AWG, Allen PF, Moynihan PJ. Nutritional counseling increases fruit and vegetable intake in the edentulous. J Dent Res [serial on the Internet] 2006 [cited 2010 Aug 14]; 85(5): 463-8. Available from: URL:http://jdr.sagepub.com/content/85/5/463.

4. Shinkai RSA, Hatch JP, Sakai S, Mobley CC, Saunders MJ, Rugh JD. Oral function and diet quality in a community-based sample. J Dent Res [serial on the Internet] 2001 [cited 2010 Aug 14]; 80(7): 1625-30. Available from: URL:http://jdr.sagepub.com/content/80/7/1625.

5. Bradbury J, Thomason JM, Jepson NJA, Walls AWG, Mulvaney CE, Allen PF, et al. Perceived chewing ability and intake of fruit and vegetables. J Dent Res [serial on the Internet] 2008 [cited 2010 Aug 14]; 87(8): $720-5$. Available from: URL:http://jdr.sagepub.com/content/87/8/720.

6. Zarb GA, Bolender CL, Hickey JC, Carlsson GE. Buku ajar prostodonti untuk pasien tak bergigi menurut Boucher. Ed.10. Alih bahasa: Mardjono D. Jakarta: EGC; 2002. p.84-90.

7. Thalib B. Analisis hubungan status gigi dengan pola makan dan asupan nutrisi pada manula suku Bugis dan suku Mandar. J Dentofas 2008; 7(1): 27, 36.

8. Ritchie CS, Joshipura K, Hung HC, Douglass CW. Nutrition as a mediator in the relation between oral and systemic disease: association between specific measures of adult oral health and nutrition outcomes. Crit Rev Oral Bio Med [serial on the Internet] 2002 [cited 2010 Aug 14]; 13(3): 291-300. Available from: URL:http://cro. sagepub.com/content/13/3/291.

9. Fontijn-Tekamp FA, Slagter AP, van der Bilt A, van T Hol MA, Witter DJ, Kalk W, et al. Biting and chewing in overdentures, full dentures, and natural dentition. J Dent Res [serial on the Internet] 2000 [cited 2010 Aug 14]; 79 (7): 1519-24. Available from: URL:http://jdr.sagepub.com/content/79/7/1519

10. Shigli K, Awinashe V. Patient-dentist communication: an adjunct to successful complete denture treatment. J Prosthodont 2010; 19: 491-3. 